\title{
THE EFFECT OF WEIGHT TRAINING WITH FAST AND SLOW RHYTHM MOVEMENT TOWARDS STRENGTH ENHANCEMENT
}

\author{
Kamal Firdaus \\ Padang State University, Komp. Parupuk Raya B.36 Tabing Padang West Sumatera 25171 \\ dr. Kamalfirdaus.mkes.aifo@gmail.com
}

\begin{abstract}
Strength is the most important physical conditions in doing various activities, either daily activities or sports activities. One can not do much when there is no power.

In the world of sports, generally the elements of power play a fairly important. In addition for those those truly need a power such as heavy weight, wrestling, boxing and other sports branches.
\end{abstract}

The achievements competitiveness in sports happens because there are so many prizes and bonuses which are promised when somebody becomes a champion, it makes people strive to improve their performance in many ways in terms of strength. One of the efforts is from physical exercises. Physical exercise to increase strength is by lifting weights. The impact of other forms of weight training can be done to increase the strength. In this research, the writer would only look at the effect of weight training with a fast beat and slow rhythm towards the rate of strength enhancement.

As for those who tried to be included in the study were derived from the population of boys grade I and II of SMA Negeri 3 Padang. From the total of the population, the writer randomized as many as 40 people as a sample. After these two groups underwent the initial tests, then the writer tried to divide them into 2 groups again, with each group consisting of 20 people. Before the treatment was conducted, some boys were given out the trial tests. This initial test was conducted to determine the level of initial strength owned by sample and tried to divide people into two homogeneous groups. After the sample had done the initial tests and had been divided into two groups, then for group I was given the weight training treatment with fast rhythm, while the second group was given the treatment of weight training with a slow rhythm.

Treatment was given for 2 months with the practice intensity was 3 times per week. After the sample tried to complete their training program, then do another test (final test). This second test functions to see how much the influence of the treatment given by the trainer comparing to the results of preliminary tests. From the data analysis, it can be seen that;

1. Weight training with fast rhythm movement can enhance the strength significantly $\neg$. It is based on $P$ $<0.05$ or value $\mathrm{tO}>$ from t table.

2. Weight training with slow motion rhythm can enhance the strength significantly It is based on $P$ $<0.05$ or value $\mathrm{tO}>$ of the t table. There were no differences in strength enhancement by conducting the treatment of weight training with fast rhythm and slow rhythm. It is proved that $\mathrm{P}>0.05$ or value tO $<$ of $t$ table.

\section{Indexing terms/Keywords}

THE EFFECT OF WEIGHT TRAINING WITH FAST AND SLOW RHYTHM MOVEMENT TOWARDS STRENGTH ENHANCEMENT.

\section{Council for Innovative Research}

Peer Review Research Publishing System

\section{Journal: Journal of Social Sciences Research}

Vol. 8, No. 2

jssreditor.cir@gmail.com

www.jssronline.com 


\section{Academic Discipline And Sub-Disciplines}

Sport Education

\section{SUBJECT CLASSIFICATION}

Natural and Social

\section{TYPE (METHOD/APPROACH)}

\section{A. Type of Research}

The study, entitled "The Effect of Weight Training with Rapid and Slow Rhythm Movement towards Strength Enhancement " is an experimental research. In conducting the research, the writer gave treatments to the sample of population. The treatment itself could be in the form of weight training. The first group was given the weight training treatment which was done with a rapid rhythm movement. Meanwhile, the second sample was given the same treatment, but with slow rhythm movement. It was expected that the researcher could find valid results and draw conclusions.

\section{B. Re search Design}

The research design of this research was Randomized Pretest-Posttest Design. In tems of methodology, this design can be regarded as a valid and reliable method, as well as qualified for this kind of experimental research.

The design of the study can be seen in the following chart:

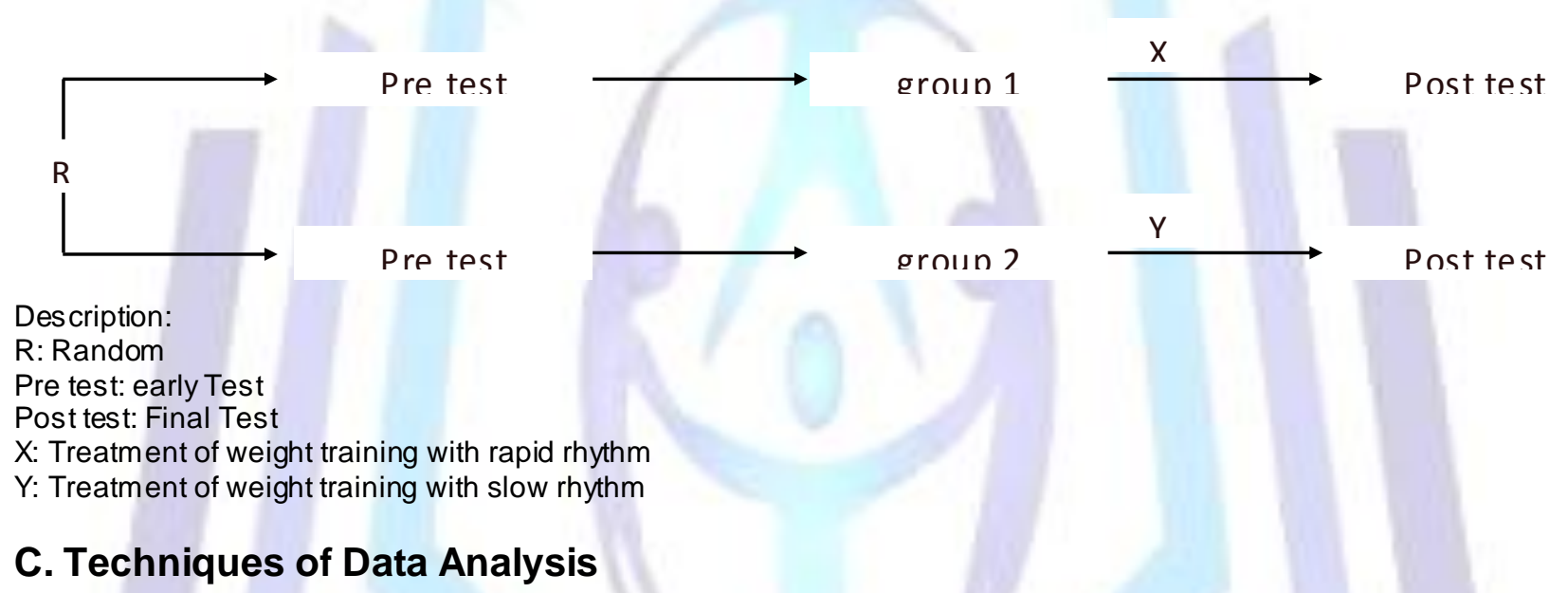

All the data obtained in this study, whether it is the primary or secondary data, processed and analyzed by using descriptive and inferential statis tics with the formula t test at a significance interval of $5 \%$ or $95 \%$ of confidence intervals.

\section{INTRODUCTION}

Many people around the world want the ideal body shape which is proportional, muscular and strong. The imagination of the perfect body shape has been in people's mind since long time ago. In ancient Greece, some sculptures made stone carving of human body shape that were more God-liked and looked more perfect. This was done by Phidias and Polycletus. By making 20 models in their research, they found the proportion of the perfect body shape, which they named the Doryphores (javelin thrower). They illustrated that the human body is the perfect body shape of a man with broad shoulders and a thick and square chest. (McArdle, 1981).

A fresh and healthy body is necessary in conducting any activities effectively and efficiently. While powerful and muscular body, can make a person's body to be chaming to look at. Not to mention in the world of sport, a strong body is one of the deciding factors for a person to achieve the expected performance. Especially for sports, it really requires power such as weight lifting, wrestling, boxing and other forms of the other sports.

To achieve the best performance and prestige in the world of sports, tempted by promising gifts, and many other benefits that can be learned, if someone won, making people attempt to enhance their capabilities. In the world of sports, it should be supported by a variety of factors to achieve a high performance, such as technical ability, physical condition, tactics and strategy. If there is any weak factor from those that are mentioned, it will disturb the other factors.

The physical condition is the most important factor of all the factors mentioned above. Since someone can not be able to learn and practice his or her techniques and others, if there is no power. The physical conditions includes; strength, endurance, speed, agility, balance, flexibility and coordination.

In the branches of non-resistance exercise (anaerobic), the elements of power, speed and flexibility, and agility are needed, even it is a decisive component for achieving the desired performance. Therefore, to improve the physical condition, the absolute physical exercise must be carried out. The physical workout that can increase the strength is by 
weight training. It is aligned with what is said by (Soekarman 1986) that: "If we want to improve performance in sports, it is absolutely necess ary to increase our strength, while the training to increase our strength is by lifting weights."

\section{CHAPTER II REVIEW OF RELATED LITERATURE}

\section{A. Muscle Strength}

Strength is the ability of a muscle or group of muscles to perform a maximal activity. According to (Costill,1986) that: "power or strength is defined as the maximum ability to resist force." Meanwhile, according to (Alan Stull, 1980); "muscle strength is the maximum amount of tension, in which the muscles can do in a single contraction". Whereas (Fox, 1988) states that; "strength can be defined as a force or strains of a muscle or group of muscles that can go through the maximum effort."

Strength is the important element of the physical condition which is dominant among the elements of the other physical conditions. Since if there is no strength, there would be no speed, durability and other conditions. It is impossible for us to do some work or even walk if there is no strength or power. Therefore, power training needs a serious attention for athletes in particular, who demand a high strength, and to improve and maintain health and physical fitness in general.

To improve the strength, the weights level should be maximal with a few repetitions. This was also pointed out by (O'Shea,1976) that: "weight training with sub-maximal weights is not going to eam maximal strength development. For example; the repetitions that are performed 1-3 times with heavy loads $90 \%$ will affect maximal strength development". In another study conducted by (Jensen,1984) reported that: "the strength will increase rapider by practicing muscle contraction approaching maximal, done with times repetitions".

\section{B. Weight Training}

A Weight training exercise is a systematic activity that is done repeatedly with heavy bars, dumbbells, or heavy stacks that progressively increases. Weight training means that in carrying out a physical exercise, body (skeletal muscle) gets load (weights burden) from outside of the body. A weight that is lifted by muscle is not the burden of the weight of the body, but is an additional burden from outside the body. For an instance lifting barbell or dumbbell.

\section{Weight Training with rapid Rhythm Movement}

A rapid rhythm movement of weight training means that lifting the weights with rapid movement. The advantage of this training method is that the number of reps (number of repetitions) is greater. However, the weakness of this method is that it can not be performed with the maximum weights of load. It is because if we do the rapid rhythm movement at the maximum weight of load, it can cause injury to the muscles and tendons (strains).

In weight training with rapid rhythm movements tend to develop speed strength and explosive power. These forms of exercise are very us eful for sports branches demanded strength and speed as well as high explosive power.

\section{Weight Training with Slow Rhythm Movement}

Weight training with a slow rhythm movement is where in the training (weight lifting exercises), the movement performed is slower. The advantage of this exercise method is that the weight load can be left up with the maximum weight. Yet, the weakness is the number of repetitions is fewer and the muscles tend to be easily strained as well as it prone to injury. Weight training with a slow movement tends to develop strength, because the weight of the load is maximal. Since the movement is slower, then the speed conditions can not be increased. This exercise program is more suitable for sports that require maximum strength. In carrying out this research, the researcher did not classify the weight to the first group and the second group. This means that weight training was given to both groups was the same as that of the maximum power of each. The thing that was different was the speed of the movement, where the first group did the exercise with a rapid movement, while the second group did it a with slow rhythm movement.

\section{The Training Effects towards Body}

By conducting weight training done with either rapid or slow rhythm movement, it will definitely increase strength and muscle hypertrophy, due to the weight, then the nervous system that control the contraction and relaxation of muscles will be more aroused. This will affect the increase in muscle strength.

According to (Fox, 1988), it is stated that: "there are two possibilities of the nervous system that affects muscle strength;

1) With the increasing number of motor units involved in each muscle contraction.

2) An increase in stimulation of the each motor unit itself.

Meanwhile, according to (Larry G. Shaver,1981), it is stated that: "weight training might cause muscle hypertrophy as a result of changes in : a) the increase of the total number of myosin, actins and other myofibril proteins, b) the increase the total number of contractile protein, myofibrils per fiber, c) the increase in large and strength of connective tissue, ligame nts and tendons, d) the increase of blood circulation network (capillaries and venules) per fiber, and e) Increasing the concentration of myoglobin, as well as other biochemical changes".

\section{CHAPTER III RESEARCH METHOD}




\section{A. Type of Research}

The study, entitled "The Effect of Weight Training with Rapid and Slow Rhythm Movement towards Strength Enhancement " is an experimental research. In conducting the research, the writer gave treatments to the sample of population. The treatment itself could be in the form of weight training. The first group was given the weight training treatment which was done with a rapid rhythm movement. Meanwhile, the second sample was given the same treatment, but with slow rhythm movement. It was expected that the researcher could find valid results and draw conclusions.

\section{B. Research Design}

The research design of this research was Randomized Pretest-Posttest Design. In terms of methodology, this design can be regarded as a valid and reliable method, as well as qualified for this kind of experimental research.

The design of the study can be seen in the following chart:

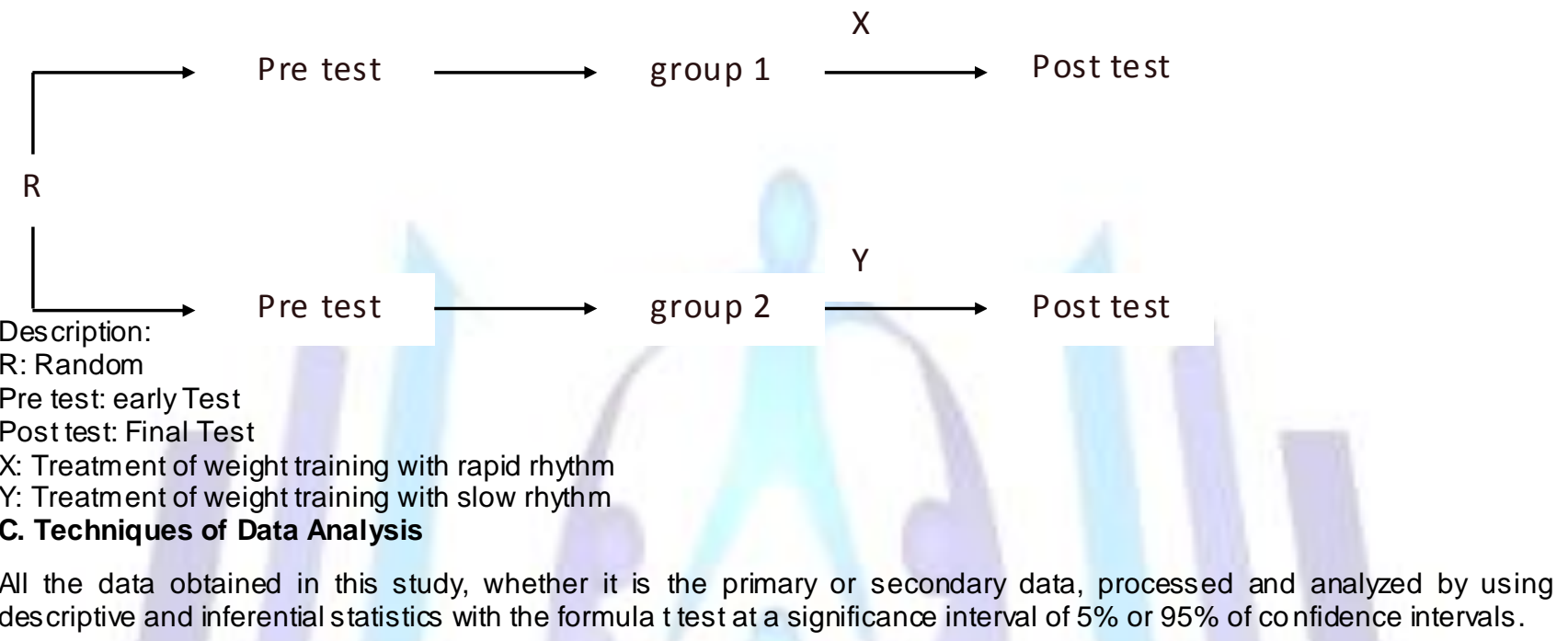

\section{CHAPTER IV RESEARCH FINDINGS}

\section{A. De scription of the Data}

Based on the result of the pre test and post test towards the level of strength of both sample, it could be obtained the following results:

Initial Test (Pre Test)

Data obtained from the initial measurement of the level of strength is:

Table 1

Initial Strength Test

\begin{tabular}{|c|c|c|c|c|c|c|c|}
\hline Nb. & strength & Nb. & strength & Nb. & strength & Nb. & strength \\
\hline $\mathbf{1}$ & 126 & $\mathbf{1 1}$ & 142 & $\mathbf{2 1}$ & 165 & $\mathbf{3 1}$ & 112 \\
\hline $\mathbf{2}$ & 165 & $\mathbf{1 2}$ & 142 & $\mathbf{2 2}$ & 157 & $\mathbf{3 2}$ & 102 \\
\hline $\mathbf{3}$ & 200 & $\mathbf{1 3}$ & 84 & $\mathbf{2 3}$ & 175 & $\mathbf{3 3}$ & 260 \\
\hline $\mathbf{4}$ & 155 & $\mathbf{1 4}$ & 133 & $\mathbf{2 4}$ & 133 & $\mathbf{3 4}$ & 125 \\
\hline $\mathbf{5}$ & 149 & $\mathbf{1 5}$ & 53 & $\mathbf{2 5}$ & 125 & $\mathbf{3 5}$ & 115 \\
\hline $\mathbf{6}$ & 125 & $\mathbf{1 6}$ & 136 & $\mathbf{2 6}$ & 154 & $\mathbf{3 6}$ & 164 \\
\hline $\mathbf{7}$ & 124 & $\mathbf{1 7}$ & 115 & $\mathbf{2 7}$ & 150 & $\mathbf{3 7}$ & 163 \\
\hline $\mathbf{8}$ & 115 & $\mathbf{1 8}$ & 108 & $\mathbf{2 8}$ & 100 & $\mathbf{3 8}$ & 147 \\
\hline $\mathbf{9}$ & 92 & $\mathbf{1 9}$ & 150 & $\mathbf{2 9}$ & 127 & $\mathbf{3 9}$ & 106 \\
\hline $\mathbf{1 0}$ & 145 & $\mathbf{2 0}$ & 155 & $\mathbf{3 0}$ & 175 & $\mathbf{4 0}$ & 150 \\
\hline
\end{tabular}

Based on table above, it can be seen that the total score of initial strength test was 5519 with average score 137.97 . The highest score was 260 , and the lowest score was 53. 
Before the treatment was given, the writer tried to divide the sample into two groups. The group division was done in order to avoid a significant difference between the groups (homogeneous), so that if there is a difference in the final test results were an actual effect of the treatment. The results of initial tests and classification can be seen in table 2 .

Table 2

Initial Test Re sults and Classification

\begin{tabular}{|c|c|c|c|c|c|c|c|}
\hline \multicolumn{4}{|c|}{ group 1 } & \multicolumn{4}{c|}{ group 2 } \\
\hline Nb. & result & Nb. & result & Nb. & result & Nb. & result \\
\hline 1 & 260 & 11 & 126 & 21 & 175 & 31 & 142 \\
\hline 2 & 200 & 12 & 125 & 22 & 165 & 32 & 136 \\
\hline 3 & 175 & 13 & 125 & 23 & 164 & 33 & 133 \\
\hline 4 & 165 & 14 & 124 & 24 & 163 & 34 & 133 \\
\hline 5 & 155 & 15 & 115 & 25 & 157 & 35 & 125 \\
\hline 6 & 154 & 16 & 115 & 26 & 155 & 36 & 115 \\
\hline 7 & 150 & 17 & 112 & 27 & 150 & 37 & 108 \\
\hline 8 & 149 & 18 & 102 & 28 & 150 & 38 & 106 \\
\hline 9 & 145 & 19 & 100 & 29 & 147 & 39 & 84 \\
\hline 10 & 127 & 20 & 92 & 30 & 142 & 40 & 53 \\
\hline
\end{tabular}

Based on the initial test results and classification, the total score obtained by the first group was 2816 with an average value of 140.8. The highest score was 260 and the lowest score was 92 . The total score of the second was 2703 with an average value of 135.2. The highest score was 175 and the lowestscore was 53.

\section{Final Test Results (Post Test)}

To see the effect of the treatment, after doing the exercises for 2 months, then each group performed another test (final test). The results of the test

\section{a. The results of the final test of group 1}

Table 3

The results of the final test of group 1

\begin{tabular}{|c|c|c|c|c|c|c|c|}
\hline Nb. & result & Nb. & result & Nb. & result & Nb. & result \\
\hline 1 & 265 & 6 & 158 & 11 & 130 & 16 & 120 \\
\hline 2 & 209 & 7 & 155 & 12 & 131 & 17 & 118 \\
\hline 3 & 183 & 8 & 157 & 13 & 130 & 18 & 120 \\
\hline 4 & 170 & 9 & 152 & 14 & 129 & 19 & 113 \\
\hline 5 & 159 & 10 & 132 & 15 & 123 & 20 & 102 \\
\hline
\end{tabular}

Based on the data obtained in the final test for group 1, the total score obtained was 2956 with an average score of 147.8 . While the highest score was 265 and the lowest score was 102. b. The results of the final test group 2

Table 4

The results of the final test of group 2

\begin{tabular}{|c|c|c|c|c|c|c|c|}
\hline Nb & result & Nb. & result & Nb. & result & Nb. & result \\
\hline 1 & 184 & 6 & 162 & 11 & 145 & 16 & 129 \\
\hline 2 & 169 & 7 & 160 & 12 & 138 & 17 & 117 \\
\hline 3 & 171 & 8 & 159 & 13 & 138 & 18 & 112 \\
\hline 4 & 167 & 9 & 153 & 14 & 140 & 19 & 100 \\
\hline 5 & 161 & 10 & 146 & 15 & 130 & 20 & 78 \\
\hline
\end{tabular}


Based on the data obtained in the final test for group 2, the total score obtained was 2859 with an average score of 142.9. While the highest score was 184 and the lowest score was 78.

\section{B. Data Analysis}

1. The results of the initial test

To prove that the initial strength of group 1 to group 2 is in a homogeneous, then the writer conducted the t-test. Based on the analysis, it was obtained that $\mathrm{P}>0.05$. or tO smaller than t table $(1,069<2,093)$. It can be concluded that between group 1 and group 2 there was no significant difference (homogeneous).

2. The results of the final test

After conducting the initial tests and it was certain that there was no difference between the groups, then the two groups were given a treatment. After each group had done all the treatment, they were carried out the second test (final). Based on the analysis, it was obtained that $\mathrm{P}>0.05$ or tO was less than the value of t table $(0970<2093)$. It can be concluded that there was no significant difference between the increases of strength of group 1 with group 2.

\section{a. The Effect of treatment in group}

To see the improvement that occurred during the treatment given, it must be performed the t-test during pre-test and post test. Based on the analysis done by the researcher, it was obtained results as follows:

1) The effects of treatment in group 1

Based on the analysis, $\mathrm{P}<0.05$ or tO was greater than the value of table (8997> 2093). It can be concluded that there was a difference between the pre-test and post-test in group 1. In other words, weight training with rapid rhythm movement strength.

2) the effects of treatment in group 2

Based on the analysis, $\mathrm{P}<0.05$ or the value of tO was greater than t table (6488>2093). It can be concluded that in group 2 there was significant differences between the pre-test and post-test. In other words, weight training with slow rhythm movement might also increase strength.

Based on the above analysis, it can be summed up that the first and second hypothesis proposed in this study, might be accepted as true. Yet, the third hypothes is turned out to be rejected. However, based on the mean difference between the post test results obtained by group 1 and group 2 have showed differences. This can be seen in table 5 , the mean obtained at post test of group 1 is greater than the mean obtained in group 2 as well as the total score.

\section{Table 5}

the Mean Score Differences and Total Score Between Group 1 and Group 2

\begin{tabular}{|c|c|c|c|c|}
\hline Test Type & \multicolumn{2}{|c|}{ Group 1 } & \multicolumn{2}{c|}{ Group 2 } \\
\hline & Mean & Total & Mean & Total \\
\hline Pre test & 140.8 & 2816 & 135.1 & 2703 \\
\hline Post test & 181.1 & 3622 & 161.9 & 3238 \\
\hline Differences & 40.3 & 806 & 26.8 & 535 \\
\hline
\end{tabular}

\section{CHAPTER V CONCLUSIONS AND RECOMMENDATIONS}

\section{A. Conclusion}

Based on the results of findings and discussion, it can be concluded as follows;

1) Weight training with rapid rhythm movement can increase the strength significantly $(P<0.05)$ or the value of tO> t table.

2) Weight training with slow rhythm movement can increase strength significantly $(P<0.05)$ or to $>t$ table.

3) There was no significant difference between the increase of strength in group 1 with group $2(P>0.05)$ or $t O<t$ table.

\section{B. Suggestion}

1) To increase muscle strength, both forms of exercises can be applied with a proper technique.

2) It is expected that there will be further researches that discuss more this weight training. 


\section{REFERENCES}

[1] Alan Stull. (1980). Encyclopedia of Physical Education Fitness and Sport. Bringhton Publishing Company.

[2] Costill, D.L. (1983). Training for Sport and Activity: The Physiological basis of conditioning process. 3rd Ed. Wm.C.Brown Publishers. United State of America.

[3] Dirix. (1988). The Olympic Book Of Sports Medicine. Blackwell Scientific Publication. Melbourne.

[4] Fox, E.L. Bower. (1988). The Physiological Basis of Physical Education and Athietics. Iladelphia, Saunders Collegge Publishing.

[5] Jensen, C.R. (1986). Applied Kinesiology and Biomechanics. 3th. Ed. Mc Gram Hill Book Company, New York.

[6]Lary, G.S. (1981). Essentials of Exercise Physiology. Minnea Pons, Minenesota, Burgess Publishing Company.

[7] McArdle, W.D. (1931). Exercise Physiology, Energy, Nutrition and Human Performance. Lea Febriger, Philadelphia.

[8] O'Shea, J.P. (1976). Scientific Principles and Methods of Strength Fitness. 2nd. Ed. Wesley Publishing Co. California.

[9] Sukarman. (1938). Bagaimana Cara Memperkuat Otot (program Latihan Kekuatan).

[10] William, A.G.( 1988). Advences in Sports Medicine and Fitness. Vol. 1. Year Book Medical Publisher, Inc, Chicago.

\section{CURICULUM VITAE}

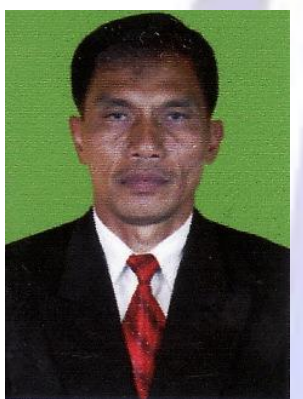

Firdaus Kamal, born in Jambi 12 Novembers 1962, was the second of Mr. H. Sutan Pameran (Alm) and Mrs. Hj. Elzas M. (from Bukittinggi).

Married to Agusnelly and happing a child named Rahmat Al Aziz katialy, Student of Pembangunan UNP Senior High School.

Education finish his Primary School in SD Negeri 01 Bajubang Jambi in 1975, High School in Bajubang Jambi in 1978, Senior Figh School in Bajubang Jambi in 1981, and Sport Science Faclity, Institute a Science Theacher and Science Education of Padang in 1985, in 1997 continued Megister Program Sport Science in Airlangga Univercity and finisehed 1999, in 2009 continued Doctor Program Sport Education Studies in Semarang Univercity and finished 2012.

In 1987 appointed School Theacher Gym Teacher and in 1990 moved to the transition to Institute a Science Theacher and Science Education of Padang until now.

Scientific Activities, Sport Science Thecnology (Scientific Papers, 1998), PB Pelti Instructur (Workshop, 1994), The Role of Secology, Psychology and Sports Bisiness in Supporting the Improvemen of Sports Performence (Symposium, 1997), Internasional Tenis Federation Coaching Workshop (2000), Intersection Scientific Work of Science and Thecnology of Sports (Works hop, 2007).

Scientific Work (Book), General Science of Sport (UPI Bandung, 2003), Sports Marketing (UPI Bandung, 2006), Sport Management (UPI Bandung, 2008). 